\title{
PENGGUNAAN ATRAKTOR UMPAN IKAN RUCAH TERHADAP HASIL TANGKAPAN BAGAN APUNG DI TELUK PALABUHANRATU
}

\author{
Using Fish Trash as Bait Atractor due to Catch of Fish by the Floating Liftnet in Palabuhanratu Bay \\ Oleh : \\ Josat Ilyazuth Zalzati ${ }^{1}$, Zulkarnain ${ }^{{ }^{*}}$, Sulaeman Martasuganda ${ }^{1}$ \\ ${ }^{1}$ Departemen Pemanfaatan Sumberdaya Perikanan, FPIK-IPB \\ "Korespondensi: zulkarnain@apps.ipb.ac.id
}

\begin{abstract}
ABSTRAK
Tujuan penelitian untuk memberikan informasi mengenai komposisi ikan hasil tangkapan bagan apung penelitian dan pengaruh penggunaan umpan ikan rucah pada alat tangkap bagan apung yang dibandingkan dengan bagan apung standar yang biasa nelayan gunakan di Teluk Palabuhanratu. Pengambilan data dilaksanakan di Teluk Palabuhanratu, Kabupaten Sukabumi, dengan metode experimental fishing. Pengambilan data dilakukan dengan melakukan kegiatan operasi penangkapan ikan secara langsung di lapangan. Analisis data yang digunakan yaitu analisis deskriptif dan analisis statistik. Hasil penelitian menunjukkan bahwa hasil tangkapan bagan apung yang dioperasikan sebanyak 19 kali ulangan memperoleh 14 jenis ikan hasil tangkapan dengan total berat hasil tangkapan sebesar 1356,58 kg. Perlakuan dari penggunaan umpan ikan rucah telah memberikan pengaruh yang nyata terhadap berat total hasil tangkapan yakni bagan apung dengan umpan ikan rucah memperoleh ikan hasil tangkapan seberat $961,58 \mathrm{~kg}$, sedangkan bagan apung tanpa umpang memperoleh ikan hasil tangkapan seberat $395 \mathrm{~kg}$.
\end{abstract}

Kata Kunci : Bagan apung, ikan rucah, penggunaan atraktor, Teluk Palabuhanratu, umpan ikan rucah.

\begin{abstract}
The purpose of the study was to provide information about the composition of the catch from the research floating liftnet and the effect of using trash fish bait on floating liftnet compared to the catch from the standard floating liftnet that fishermen used at the bay of Palabuhanratu. Data collection was carried out in bay of Palabuhanratu, Sukabumi Regency, with experimental fishing methods. Data collection is carried out by conducting fishing operations directly in the field. Data analysis used is descriptive analysis and statistical analysis. The results of the study showed that 19 catches of the operated floating liftnet obtained 14 species of caught fish with a total weight of the catch of 1356,58 $\mathrm{kg}$. the treatment of the use of trash fish bait had a significant effect on the total weight of the catch, from the floating liftnet with trash fish bait obtained catching fish weighing $961,58 \mathrm{~kg}$, while the floating liftnet without bait obtained catch fish weighing $395 \mathrm{~kg}$.
\end{abstract}

Keywords: Floating liftnet, trash fish, using attractors, Bay of Pelabuhanratu, trash fish bait.

\section{PENDAHULUAN}

Bagan apung merupakan salah satu jenis alat penangkap ikan yang banyak digunakan di teluk Palabuhanratu. Bagan apung dioperasikan pada malam hari dengan menggunakan alat bantu penangkapan ikan berupa atraktor cahaya lampu listrik yang sumber tenaganya berasal dari genset. Atraktor cahaya lampu digunakan bertujuan untuk mengumpulkan ikan yang mempunyai sifat fototaksis positif. Fototaksis merupakan peristiwa terangsangnya organ pengelihatan ikan terhadap 
cahaya (Ayodhyoa 1976). Ikan yang berfototaksis positif akan berkumpul di daerah cahaya lampu sehingga memudahkan nelayan dalam melakukan proses penangkapan (Hasan 2008). Nelayan bagan apung di teluk Palabuhanratu selain menggunakan cahaya lampu di atas permukaan air juga digunakan lampu tambahan berupa lampu celup bawah air. Lampu celup bawah air (Lacuba) merupakan alat pemanggil ikan berupa lampu kedap air yang digunakan oleh nelayan untuk membantu penangkapan ikan, yang mana penggunaan lacuba dengan cara dicelupkan ke dalam air (Brown 2013).

Selain alat bantu penangkapan ikan yang berupa cahaya lampu, pada bagan apung juga digunakan atraktor rumpon. Zulkarnain (2002) hasil tangkapan lebih banyak diperoleh pada bagan apung yang menggunakan rumpon dibanding bagan apung tanpa rumpon. Ikan biasanya bergerak mendekati sumber cahaya dikarenakan mencari makan atau fototaksis positif, bisa juga karena keduanya yaitu mencari makan dan sifat fototaksis positif (Purbayanto et al. 2010). Sumber makanan selain yang ada di dalam perairan, salah satu alternatif sumber makanan lainnya berasal dari umpan, yang mana umpan dapat digunakan sebagai atraktor pada penangkapan ikan. Efektivitas umpan ditentukan oleh sifat fisik dan kimiawi pada umpan agar dapat memberikan respon terhadap ikan-ikan tertentu (Subani dan Barus 1989).

Pada penelitian ini dilakukan penambahan penggunaan atraktor umpan ikan rucah sebagai atraktor tambahan selain lampu. Jenis ikan rucah yang biasa digunakan sebagai umpan diantaranya ikan tembang, ikan pepetek, ikan teri dan udang rebon. Alasan penggunaan umpan ikan rucah yaitu karena kandungan asam amino yang tinggi pada ikan rucah yang dapat memikat penciuman ikan target tangkapan. Kandungan asam amino yang terdapat pada ikan rucah terdiri atas serin, glisin, histidin, arginin, threonin, alanin, prolin, tirosin, valin, methionin, sistin, isoleusin, leusin, phenilalanin dan lisin (Fitri 2008). Dilihat dari kandungan asam amino yang dapat merespon nafsu makan ikan terdapat kandungan yang dimiliki oleh ikan rucah seperti alanin, arginin, methionin, leusin dan prolin sehingga ikan rucah dapat merangsang organ penciuman ikan.

Penelitian tentang penggunaan atraktor umpan pada bagan apung dilakukan karena adanya dugaan pada saat jaring mulai bergerak ke permukaan air pada saat kegiatan hauling, ikan-ikan yang telah berada di area cakupan penangkapan (Catchable area) akan bergerak menjauhi bagan. Atraktor umpan digunakan dengan tujuan supaya ikan-ikan yang bergerak menjauhi bagan tidak akan bergerak terlalu jauh dari area penangkapan sehingga hasil tangkapan ikan akan meningkat.

Penelitian ini bertujuan untuk menentukan komposisi ikan hasil tangkapan bagan apung penelitian serta menentukan pengaruh penggunaan umpan ikan rucah pada alat tangkap bagan apung yang dibandingkan dengan bagan apung standar yang biasa nelayan gunakan di Teluk Palabuhanratu.

\section{METODE PENELITIAN}

Pengambilan data dilaksanakan pada bulan Juli hingga September 2018, bertempat di Teluk Palabuhanratu, Kabupaten Sukabumi, Provinsi Jawa Barat. Metode penelitian yang digunakan adalah experimental fishing. Jenis data dalam penelitian ini adalah data primer yang didapatkan dari eksperimen langsung di lapangan. Pengambilan data dilakukan pada musim puncak ikan serta pada kondisi cuaca dan perairan yang baik. Data yang diambil berupa data waktu setting alat tangkap bagan apung, waktu hauling alat tangkap bagan apung, pengukuran berat ikan total per jenis ikan per hauling, jumlah setting dan hauling per trip, dan suhu permukaan air laut. Perlakuan pada bagan penelitian yaitu dengan menambahkan 5 buah kantung umpan diisi umpan ikan rucah sebanyak \pm 500 gram per kantung umpan per hari, sedangkan untuk bagan pembanding yaitu bagan standar nelayan Palabuhanratu. Data diambil dengan asumsi kondisi kedua bagan sama yaitu ukuran bagan, alat bantu penangkapan serta kondisi perairan di sekitar bagan. Bagan yang digunakan berukuran $6 \times 6 \mathrm{~m}$ dengan tinggi dari permukaan air laut 2 meter. Alat bantu yang digunakan pada kedua bagan yaitu lampu 45 watt berjumlah 13 buah dan lampu celup bawah air berjumlah 1 buah, serok, roller serta genset sebagai sumber listrik bagan. 

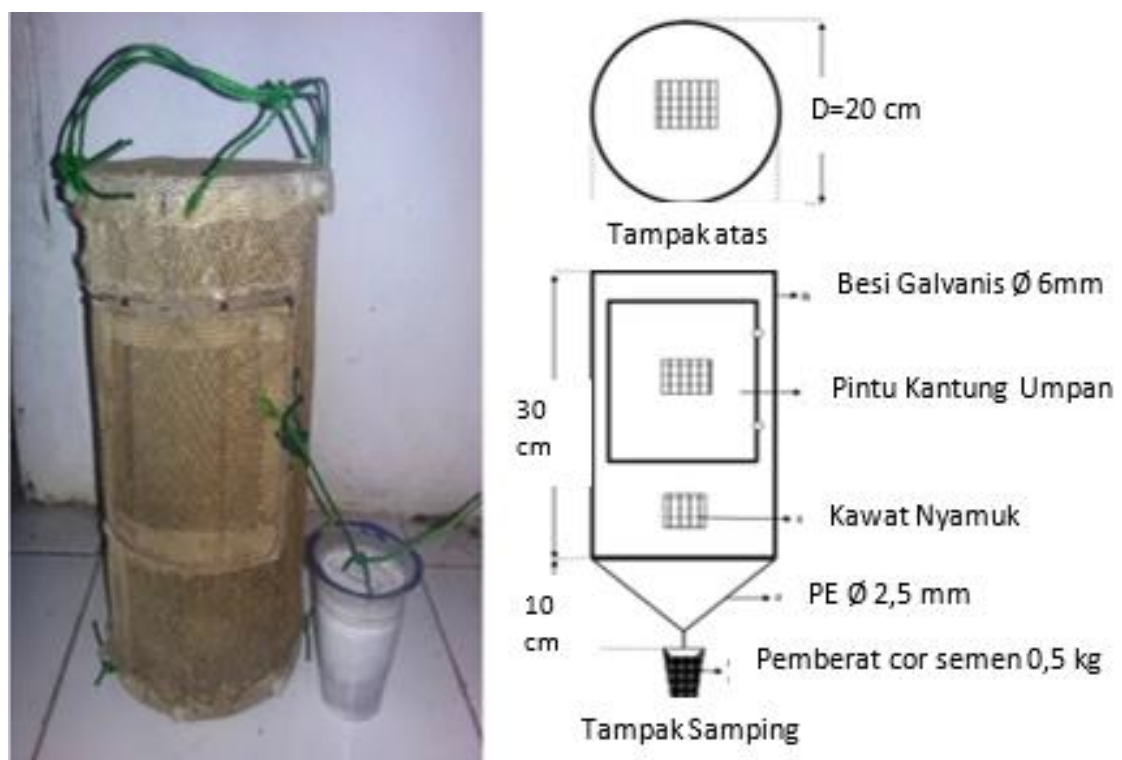

Gambar 1 Atraktor Umpan dengan Pemberat

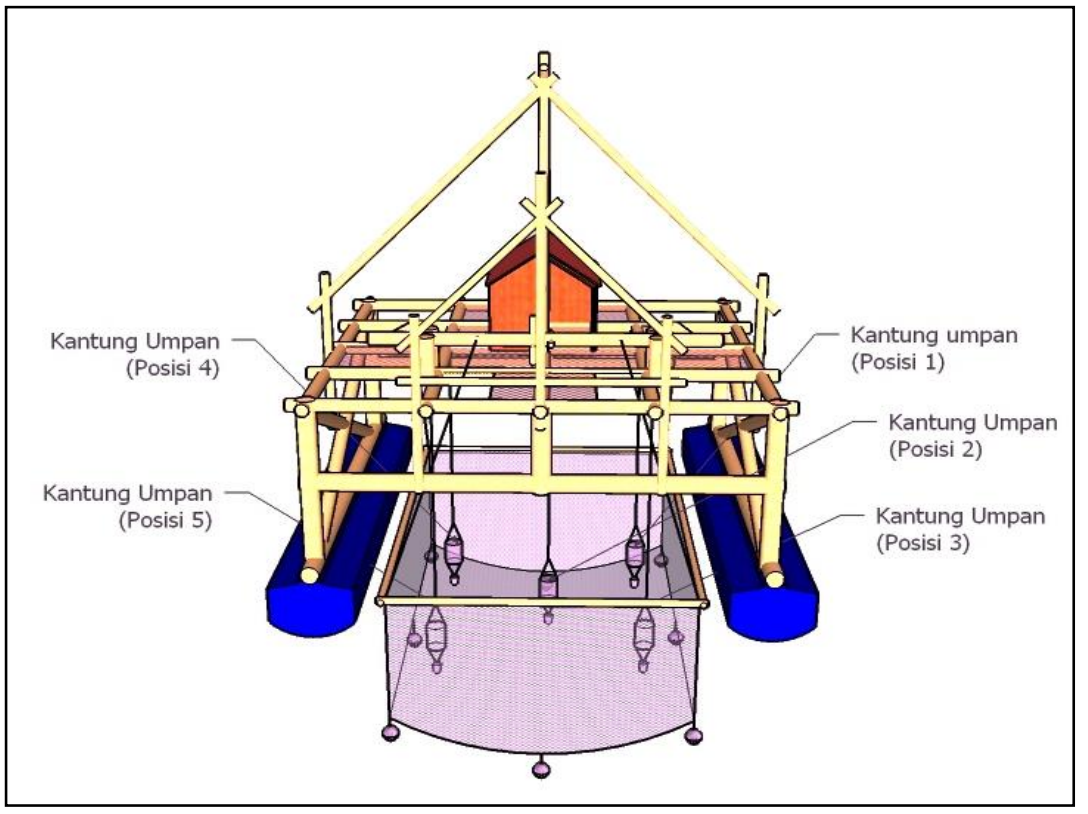

Gambar 2 Bagan Apung dengan Atraktor Umpan (Tampak Depan)

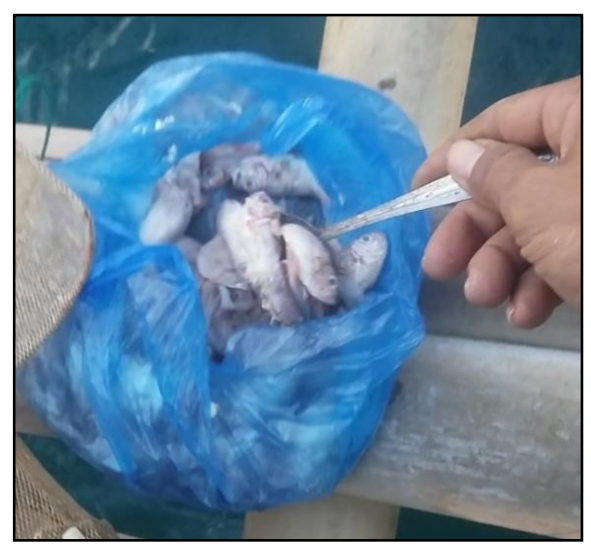

Gambar 3 Umpan Ikan Rucah 


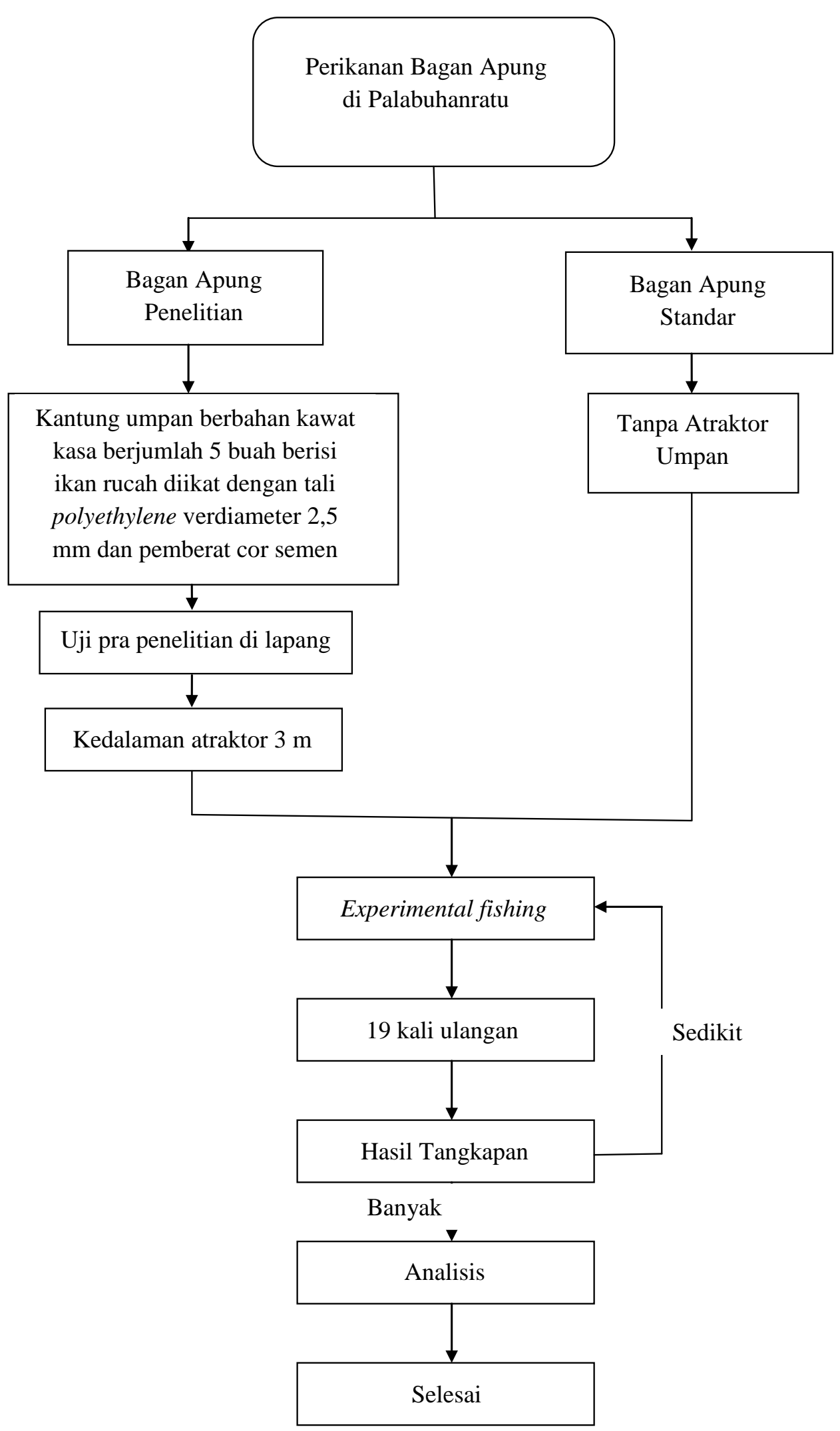

Gambar 4 Bagan alir penelitian 
Analisis yang dilakukan pada penelitian ini terdapat dua macam analisis, yaitu:

1. Analisis Deskriptif

Data hasil tangkapan disajikan dalam bentuk tabel beserta diagram, kemudian dianalisis secara deskriptif menurut pokok-pokok pembahasan seperti komposisi total hasil tangkapan bagan apung, hasil tangkapan bagan apung pada bagan yang berbeda, jenis ikan dominan hasil tangkapan dan jumlah hauling bagan dari 19 kali trip penangkapan.

2. Analisis Statistik

a. Uji kenormalan data

Uji Kenormalan merupakan sebuah uji yang dilakkan dengan tujuan untuk menilai sebaran data atau variabel, apakah sebaran data tersebut berdistribusi normal atau tidak

b. Uji t

Uji t merupakan jenis statistik parametrik untuk menilai apakah rata-rata (mean) dan keragaman (variance) dari dua kelompok berbeda secara statistik satu sama lain. Syarat melakukan uji t ini yaitu data harus menyebar normal. Sehingga uji t merupakan kelanjutan setelah uji kenormalan data.

c. Uji Mann Whitney

Uji Mann Whitney merupakan uji statistik non parametrik. Biasanya digunakan untuk menguji 2 sampel bebas atau independen (Walpole 1995). Penelitian ini menggunakan uji Mann Whitney 2 sampel independen, dikarenakan data yang didapat tidak menyebar normal. Adapun dasar keputusan yang akan diambil dalam uji ini adalah:

1) Jika nilai Jika Asymp.Sig. $(2$-tailed $)<(\alpha)$ maka tolak $H O$, berarti perlakuan kedua bagan memberikan pengaruh nyata terhadap hasil tangkapan.

2) Jika Asymp.Sig.(2-tailed) $>(\alpha)$ maka gagal tolak $H O$, berarti perlakuan kedua bagan tidak memberikan pengaruh nyata terhadap hasil tangkapan.

Hipotesis atau kesimpulan yang akan diambil :

HO: Tidak terdapat pengaruh antara kedua bagan terhadap hasil tangkapan

$H 1$ : Terdapat pengaruh antara kedua bagan terhadap hasil tangkapan.

Analisis dilakukan pada taraf $(\alpha)=0,05$, dengan jumlah ulangan $(n)=19$ kali

Rumus uji Mann Whitney untuk sampel kecil (n1 atau n2 $\leq 20)$

$$
u 1=n 1 . n 2+\frac{n 2(n 2+1)}{2}-\sum R 2 \quad u 2=n 1 . n 2+\frac{n 1(n 1+1)}{2}-\sum R 1
$$

Keterangan:

$\mathrm{U} 1$ = Statistik uji U1

$\mathrm{U} 2$ = Statistik uji U2

$\mathrm{n} 1=$ Banyaknya anggota sampel 1

$\mathrm{n} 2$ = Banyaknya anggota sampel 2

R1 = Jumlah rank sampel 1

R2 = Jumlah rank sampel 2

\section{HASIL DAN PEMBAHASAN}

Umpan merupakan salah satu faktor penting untuk menunjang keberhasilan suatu operasi penangkapan ikan karena dapat berpengaruh pada daya tarik dan rangsangan ikan (Gunarso 1985). Menurut Stoner (2004) menjelaskan bahwa pada kebanyakan kasus, ikan akan tertarik pada umpan melalui isyarat kimia terlebih dahulu ketika umpan belum dapat dideteksi oleh organ penglihatan sehingga organ penciuman yang lebih dominan berperan. Apabila bentuk umpan telah diketahui posisinya sesuai dengan maksimum sighting distance dan kekontrasannya dengan latar belakang kondisi perairan maka organ penglihatan yang lebih dominan/berperan sehingga ikan akan mendekati dan akhirnya memakan umpan/makanan tersebut (Purbayanto et al. 2010). Menurut Zulkarnain (2011), umpan yang mengandung asam amino diidentifikasi dapat menjadi stimuls dan atraktor makan pada ikan dan crustacea. Hampir semua studi mengenai rangsangan kimia untuk tingkah laku makan 
ikan menunjukkan bahwa rangsangan makan ikan akan hilang seiring dengan hilangnya kandungan asam amino pada umpan.

Beberapa faktor yang mempengaruhi pengoperasian bagan apung diantaranya suhu dan kondisi gelombang. Kondisi gelombang juga harus diperhatikan dalam pengoperasian bagan. Gelombang menyebabkan cahaya yang masuk ke air terpencar sehingga kurang maksimal untuk menarik ikan (Syahputra et al. 2016). Simbolon (2007) menyatakan bahwa pengaruh suhu perairan terhadap sebaran ikan sangat tergantung pada variabilitas suhu itu sendiri. Jika sebaran suhu perairan masih berada pada kisaran nilai yang dapat ditoleransi ikan, maka suhu perairan umumnya tidak berpengaruh secara nyata terhadap keberadaan ikan. Sehingga menurut Safruddin dan Zainuddin (2007), informasi mengenai sebaran suhu permukaan laut sangat penting untuk menentukan daerah potensial penangkapan ikan. Informasi tersebut berguna bagi nelayan untuk menentukan dimana nelayan harus melakukan operasi penangkapan ikan.

\section{Komposisi Total Hasil Tangkapan Bagan Apung}

Tabel 1 Komposisi hasil tangkapan bagan apung

\begin{tabular}{|c|c|c|c|c|c|c|c|c|}
\hline \multirow{3}{*}{\multicolumn{2}{|c|}{ No }} & \multirow{2}{*}{\multicolumn{3}{|c|}{ Jenis Ikan }} & \multicolumn{4}{|c|}{ Berat } \\
\hline & & & & & $\begin{array}{r}\text { Bagan } \\
\text { dengan } \\
\text { Ikan } \\
\end{array}$ & $\begin{array}{l}\text { Ipung } \\
\text { Jmpan } \\
\text { ucah }\end{array}$ & $\begin{array}{r}\text { Bagan } \\
\text { Tanpa }\end{array}$ & $\begin{array}{l}\text { Apung } \\
\text { Jmpan }\end{array}$ \\
\hline & & $\begin{array}{l}\text { Nama } \\
\text { Lokal }\end{array}$ & $\begin{array}{l}\text { Nama } \\
\text { Inggris }\end{array}$ & Nama Latin & $\mathrm{Kg}$ & $\%$ & kg & $\%$ \\
\hline \multirow{10}{*}{$\frac{\frac{n}{20}}{\frac{\pi}{20}}$} & 1 & Bentrong & Mackarel & $\begin{array}{l}\text { Selar } \\
\text { crumenophthalmus }\end{array}$ & 0,29 & 0,10 & 0,00 & 0,00 \\
\hline & 2 & $\begin{array}{l}\text { Cumi- } \\
\text { cumi }\end{array}$ & Squid & Loligo sp & 48,48 & 16,67 & 10,00 & 4,42 \\
\hline & 3 & Japuh & $\begin{array}{l}\text { Round } \\
\text { Herring }\end{array}$ & Dussumieria acuta & 11,50 & 3,95 & 0,00 & 0,00 \\
\hline & 4 & Kembung & $\begin{array}{l}\text { Long } \\
\text { Jawed } \\
\text { Mackarel }\end{array}$ & Rastrelliger $s p$ & 6,00 & 2,06 & 0,00 & 0,00 \\
\hline & 5 & Layang & $\begin{array}{l}\text { Mackarel } \\
\text { Scad }\end{array}$ & Decapterus sp & 47,00 & 16,16 & 38,00 & 16,81 \\
\hline & 6 & Sarden & Sardine & Decapterus tabl & 0,45 & 0,15 & 0,00 & 0,00 \\
\hline & 7 & Teri & Anchovy & Stolephorus sp & 86,82 & 29,85 & 45,00 & 19,91 \\
\hline & 8 & Tongkol & $\begin{array}{l}\text { Tuna Fish } \\
\text { Fringescale }\end{array}$ & Auxis thazard & 10,13 & 3,48 & 0,00 & 0,00 \\
\hline & 9 & Tembang & Sardine & Sardinella gibbosa & 80,18 & 27,57 & 133,00 & 58,85 \\
\hline & & Subtotal & & & 290,85 & 100,00 & 226,00 & 100,00 \\
\hline \multirow{7}{*}{\multicolumn{2}{|c|}{ 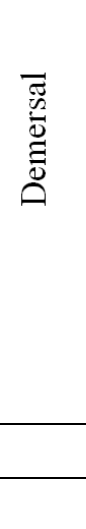 }} & Semar & Moonfish & Mene maculata & 3,00 & 0,45 & 10,00 & 5,92 \\
\hline & & Layur & Fish Belt & Trichiurus lepturus & 70,31 & 10,48 & 33,00 & 19,53 \\
\hline & & Petek & Ponyfish & $\begin{array}{l}\text { Leiognathus } \\
\text { equulus }\end{array}$ & 593,90 & 88,55 & 106,00 & 62,72 \\
\hline & & $\begin{array}{l}\text { Udang } \\
\text { Rebon }\end{array}$ & Shrimp & Acetes sp & 0,22 & 0,03 & 20,00 & 11,83 \\
\hline & & Camaul & $\begin{array}{l}\text { Puple- } \\
\text { spotted } \\
\text { Bigeye }\end{array}$ & $\begin{array}{l}\text { Priacanthus } \\
\text { tayanus }\end{array}$ & 3,30 & 0,49 & 0,00 & 0,00 \\
\hline & & Subtotal & & & 670,73 & 100,00 & 169,00 & 100,00 \\
\hline & & Total & & & 961,58 & 100,00 & 395,00 & 100,00 \\
\hline
\end{tabular}




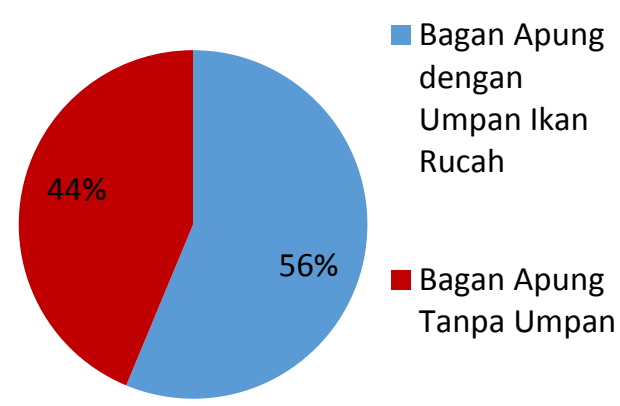

Gambar 5 Persentase Hasil Tangkapan Ikan Pelagis pada Bagan Apung

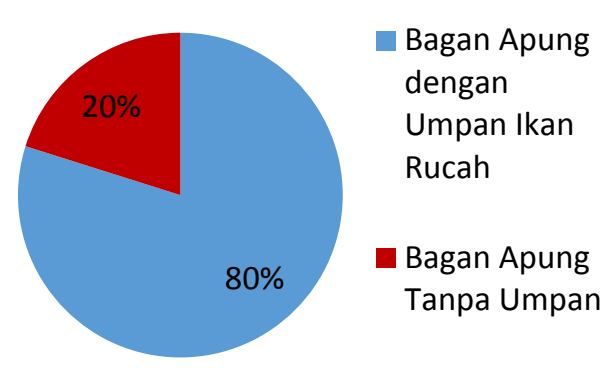

Gambar 6 Persentase Hasil Tangkapan Ikan Demersal pada Bagan Apung

\section{Komposisi Hasil Tangkapan Berdasarkan Penggunaan Umpan}

Berdasarkan hasil tangkapan pada alat tangkap bagan apung yang diberi perlakuan berbeda, diperoleh hasil tangkapan 6 jenis ikan dominan yaitu pepetek (Leiognathus $s p$ ), tembang (Sardinella gibbosa), layur (Trichiurus sp), layang (Decapterus sp), teri (Stolephorus sp) dan cumi-cumi (Loligo sp).

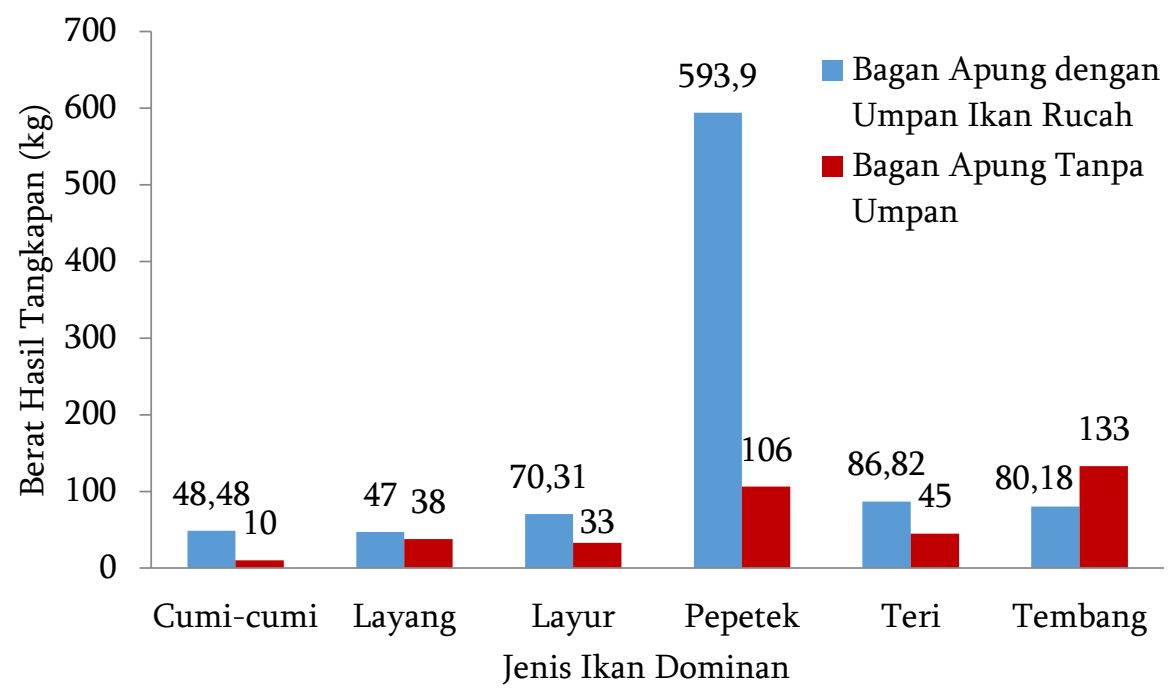

Gambar 7 Perbandingan Hasil Tangkapan Ikan Dominan

Ikan pepetek merupakan ikan hasil tangkapan terbanyak yang termasuk ikan demersal yang hidup di laut tropis dengan kisaran suhu $26-29^{\circ} \mathrm{C}$ dan bersifat fototaksis positif. Swimming layer ikan tersebut adalah di kedalaman $10-50 \mathrm{~m}$ (Utami 2009). Ikan pepetek yang tertangkap pada bagan apung dengan umpan ikan rucah memperoleh hasil tangkapan seberat 593,9 $\mathrm{kg}$ dibandingkan dengan bagan tanpa umpan memperoleh hasil tangkapan $106 \mathrm{~kg}$. Ikan tembang yang tertangkap pada bagan apung dengan umpan ikan rucah memperoleh hasil tangkapan seberat 80,18 $\mathrm{kg}$ lebih sedikit dibandingkan dengan bagan tanpa umpan memperoleh hasil tangkapan $133 \mathrm{~kg}$. Hal tersebut dikarenakan ikan tembang lebih cenderung berkumpul di daerah yang memiliki jumlah fitoplankton dan zooplankton yang tinggi seperti daerah pantai, sehingga daerah dekat pantai merupakan tempat yang disukai ikan tembang (Apriliani 2018). Ikan layur (Trichiurus sp) adalah salah satu jenis ikan demersal ekonomis penting yang banyak tersebar dan tertangkap di perairan Indonesia terutama di perairan Palabuhanratu (Sudrajat 2014). Ikan layur yang tertangkap pada bagan apung dengan umpan ikan rucah memperoleh 
hasil tangkapan seberat 70,31 kg dibandingkan dengan bagan tanpa umpan memperoleh hasil tangkapan $33 \mathrm{~kg}$. Ikan teri yang tertangkap pada bagan apung dengan umpan ikan rucah memperoleh hasil tangkapan seberat 86,82 $\mathrm{kg}$ dibandingkan dengan bagan tanpa umpan memperoleh hasil tangkapan $45 \mathrm{~kg}$. Ikan layang yang tertangkap pada bagan apung dengan umpan ikan rucah memperoleh hasil tangkapan seberat $47 \mathrm{~kg}$ dibandingkan dengan bagan tanpa umpan memperoleh hasil tangkapan $38 \mathrm{~kg}$. Cumi-cumi yang tertangkap pada bagan apung dengan umpan ikan rucah memperoleh hasil tangkapan seberat 48,48 kg dibandingkan dengan bagan tanpa umpan memperoleh hasil tangkapan $10 \mathrm{~kg}$.

Berat hasil tangkapan pada bagan yang menggunakan umpan ikan rucah lebih banyak dibandingkan dengan bagan tanpa menggunakan umpan ikan rucah, yaitu sebesar 961,575 kilogram (70,88\%) sedangkan tanpa umpan sebesar 395 kilogram (29,12\%). Perbedaan hasil tangkapan ini diduga karena adanya rangsangan penciuman ikan yang berasal dari bau umpan sehingga menarik ikan untuk datang mendekati umpan. Rangsangan untuk menarik perhatian ikan ke dalam suatu area operasi penankapan karena sifat dari jenis ikan itu sendiri yang berhubungan dengan natural behavior. Rangsangan ini dapat berupa rangsangan fisik dan kimiawi (Purbayanto et al. 2010).

\section{Hasil Analisis Statistik Uji Mann-Whitney}

Berdasarkan analisis uji Mann-Whitney statistik pengaruh perbedaan penggunaan umpan terhadap hasil tangkapan ikan (kg) diperoleh nilai Asymp.Sig. $(2$-tailed $)<0.05(0.019<0.05)$. Hal ini menunjukkan bahwa perlakuan dari penggunaan umpan ikan rucah telah memberikan pengaruh yang nyata terhadap berat total hasil tangkapan. Berdasarkan uji Mann-Whitney pengaruh perbedaan penggunaan umpan terhadap jumlah hauling diperoleh nilai Asymp.Sig. $(2$-tailed $)<0,05(0.001<0.05)$. Hal ini menunjukkan bahwa adanya pengaruh yang nyata pada jumlah hauling bagan akibat perlakuan dari penggunaan umpan ikan rucah.

\section{Perbedaan Berat Total Ikan Tertangkap pada Bagan Penelitian (Umpan ikan rucah) terhadap Waktu Hauling}

Ikan Tangkapan bagan apung memiliki berat hasil tangkapan yang berbeda-beda pada perbedaan waktu hauling. Berat hasil tangkapan pada setiap jenis ikan pada perbedaan waktu hauling disajikan pada Gambar 8.

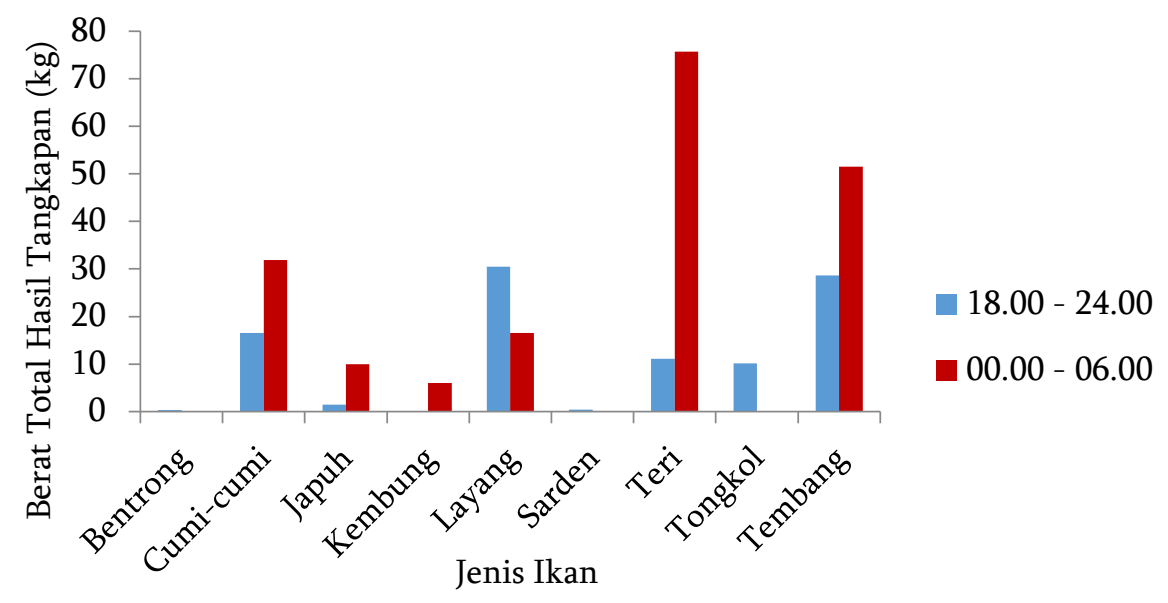

Gambar 8 Total berat ikan pelagis hasil tangkapan bagan penelitian dalam kilogram (kg) berdasarkan perbedaan waktu hauling 


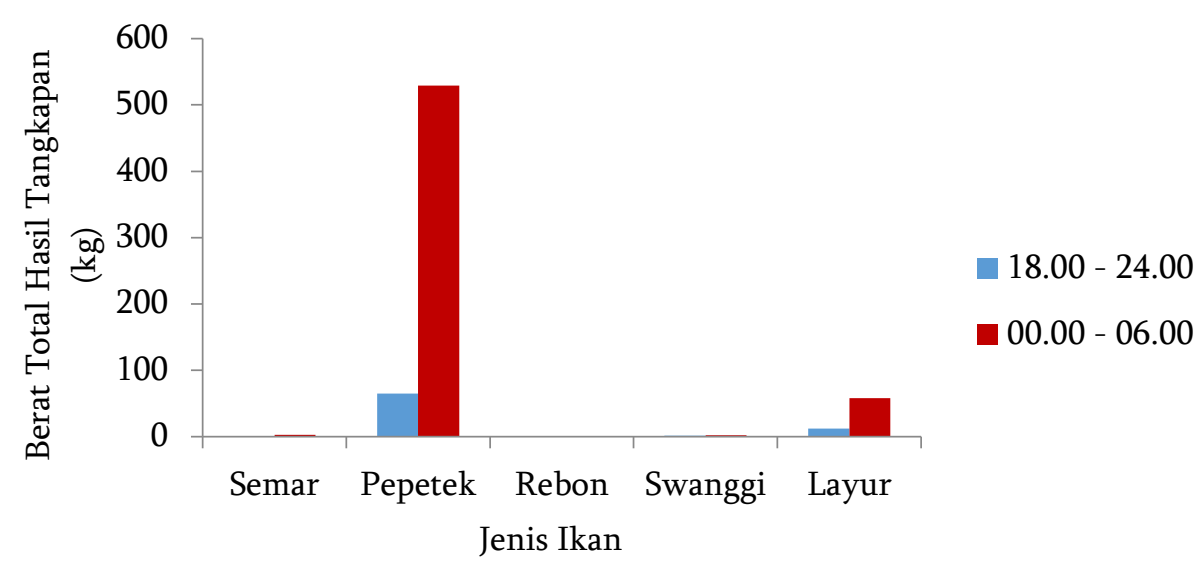

Gambar 9 Total berat ikan pelagis hasil tangkapan bagan penelitian dalam kilogram (kg) berdasarkan perbedaan waktu hauling

Ikan selar bentong, ikan layang, udang rebon, ikan sarden dan ikan tongkol mendapat total berat lebih tinggi pada pukul 18.00-24.00 WIB. Cumi-cumi, ikan japuh, ikan kembung, ikan semar, ikan layur, ikan pepetek, ikan swanggi, ikan teri dan ikan tembang mendapat total berat lebih tinggi pada pukul 24.00-06.00 WIB. Berdasarkan komposisi hasil tangkapan bagan penelitian diperoleh hasil pada pukul 24.00-06.00 WIB berat total tangkapan lebih tinggi dibandingkan pada pukul 18.00-24.00 WIB.

\section{Perbedaan Jumlah Hauling Bagan Penelitian berdasarkan Perbedaan Waktu Hauling}

Hauling yang dilakukan pada pukul 18.00-24.00 WIB memiliki jumlah yang berbeda dibandingkan pukul 24.0-06.00 WIB. Jumlah total hauling bagan Penelitian pada pukul 18.00-24.00 WIB sebanyak 24 kali sedangkan pada pukul 24.00-06.00 WIB melakukan hauling sebanyak 40 kali. Bagan penelitian memperoleh rata-rata frekuensi hauling terbanyak pada pukul 24.00-06.00 WIB dengan nilai rata-rata $\pm \mathrm{SE}$ adalah $2,11 \pm 0,13$ sedangkan pada pukul 18.00-24.00 WIB memperoleh nilai rata-rata \pm SE adalah $1,26 \pm 0,13$ (Gambar 10).

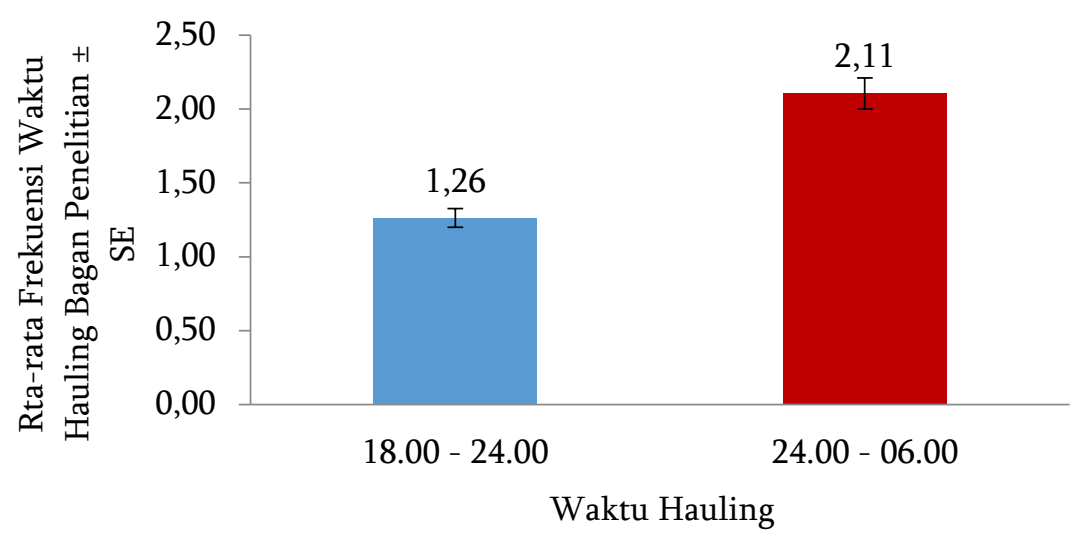

Gambar 10 Rata-rata frekuensi hauling bagan penelitian \pm SE

\section{Perbedaan Jumlah Hauling Bagan Penelitian dengan Bagan Standar}

Hauling yang dilakukan bagan penelitian memiliki jumlah yang berbeda dibandingkan hauling yang dilakukan bagan standar. Jumlah total hauling bagan penelitian sebanyak 64 kali sedangkan pada bagan standar melakukan hauling sebanyak 45 kali. Bagan penelitian memperoleh rata-rata frekuensi hauling terbanyak dengan nilai rata-rata $\pm \mathrm{SE}$ adalah $3,37 \pm 0,17$ sedangkan pada bagan standar memperoleh nilai rata-rata $\pm \mathrm{SE}$ adalah 2,37 $\pm 0,24$ (Gambar 11). 


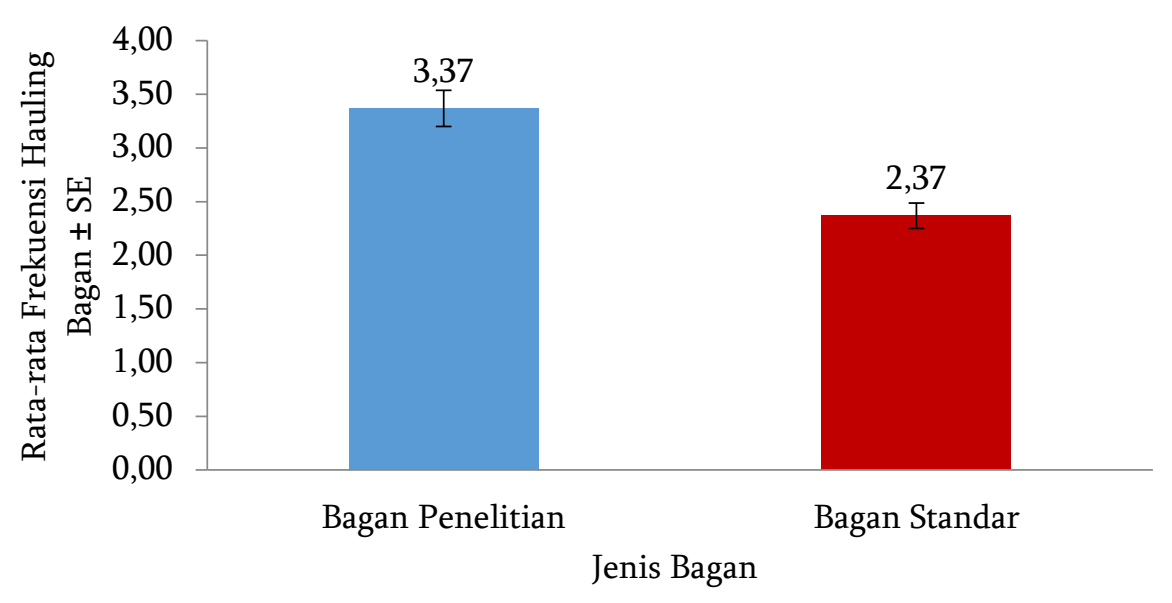

Gambar 11 Rata-rata frekuensi hauling bagan \pm SE

\section{KESIMPULAN DAN SARAN}

\section{Kesimpulan}

1. Komposisi total hasil tangkapan pada bagan apung menggunakan umpan ikan rucah terdiri dari 14 jenis ikan yaitu ikan selar bentong (Selar crumenophthalmus), cumi-cumi (Loligo sp), ikan japuh (Dussumieria acuta), ikan kembung (Rastrelliger sp), ikan kantung semar (Mene maculata), ikan layang (Decapterus $s p$ ), ikan layur (Trichiurus sp), ikan pepetek (Leiognathus $s p$ ), udang rebon (Acetes sp), ikan sarden (Decapterus tabI), ikan swanggi (Priacanthus tayanus), ikan teri (Stolephorus sp), ikan tongkol (Auxis thazard) dan ikan tembang (Sardinella gibbosa) sedangkan pada bagan apung tanpa umpan terdapat 8 jenis yaitu cumi-cumi (Loligo $s p$ ), ikan kantung semar (Mene maculata), ikan layang (Decapterus sp), ikan layur (Trichiurus sp), ikan pepetek (Leiognathus sp), udang rebon (Acetes sp), ikan teri (Stolephorus sp) dan ikan tembang (Sardinella gibbosa).

2. Bagan apung menggunakan umpan ikan rucah memberikan pengaruh nyata terhadap berat total hasil tangkapan dan jumlah hauling bagan.

Saran

Mempertimbangkan penggunaan umpan ikan rucah sebagai alternatif atraktor umpan kepada nelayan bagan sebagai implementasi paket teknologi tepat guna.

\section{DAFTAR PUSTAKA}

Apriliani, Izza M., dkk. 2018. Laju Tangkap dan Hasil Tangkapan Bagan Apung pada Jarak Penempatan Berbeda di Perairan Teluk Palabuhanratu, Sukabumi, Indonesia. Jurnal Perikanan dan Kelautan. Vol 8 Nomor 1. Juni 2018 p - ISSN 2089 - 3469 e - ISSN 2540 - 9484 Hal: 88 - 95

Ayodhyoa . 1976. Teknik Penangkapan Ikan. Bagian Teknik Penangkapan Ikan : Institut Pertanian Bogor.

Brown, Arthur et al,.2013 .Perbandingan Hasil Tangkapan Kelong (Liftnet) Menggunakan Lampu Celup Bawah Air (Lacuba) dan Petromaks di Perairan Desa Kote Kecamatan Singkep Kabupaten Lingga Propinsi Kepulauan Riau . Jurnal Akuatika, Vol. IV No. 2 Tahun 2013 (149-158)

Fitri, A D P. 2008. Respon Pengelihatan dan Penciuman Ikan Kerapu (Serranidae) terhadap Umpan dalam Efektifitas Penangkapan. [Disertasi]. Bogor (ID): Institut Pertanian Bogor. 
Fitri, A D P. 2011 . Respons Makan Ikan Kerapu Macan (Ephinephelus fuscoguttatus) Terhadap Perbedaan Jenis dan Lama Waktu Perendaman Umpan. Jurnal Ilmu Kelautan. Vol. 16 (3) Tahun 2011 Hlm 159-164

Gunarso W. 1985. Suatu Pengantar Tentang Tingkah Laku Ikan Terutama dalam Hubunganya dengan Alat Metode dan Taktik Penangkapan. [Disertasi]. Bogor (ID): Institut Pertanian Bogor.

Hasan. 2008. Uji Coba Penggunaan Lampu Lacuba Tenaga Surya Pada Bagan Apung Terhadap Hasil Tangkapan Ikan di Pelabuhan Ratu Jawa Barat. Jurnal Sains dan Teknologi Indonesia Vol.2 (3) Tahun 2000, Hlm 11-18.

Purbayanto, A., M. Riyanto, dan A.D.P. Fitri. 2010. Fisiologi dan Tingkah Laku Ikan Pada Perikanan Tangkap. PT. Penerbit IPB Press.

Simbolon, D. 2007. Pendugaan Daerah Penangkapan Ikan Tongkol berdasarkan Pendekatan Suhu Permukaan Laut Deteksi Satelit dan Hasil Tangkapan di Perairan Teluk Palabuharatu. Jurnal litbangda NTT. Kupang. No. 04: 23-30.

Safruddin dan M. Zainuddin. 2007. Mapping Scads Fishing Ground Based on the Relationship between Catch Data and Oceanographic Factors in Bone Coastal Waters. Torani Jurnal, ISSN 0853-4489. Vol. 17 (5) (Special edition : 192-200).

Stoner, A.W. 2004. Effects of Environmental Variables on Fish Feeding Ecology: Implications for ThePerformance of Baited Fishing Gear and StockAssessment (Review Paper). Journal of Fish Biology, (65):1445-1471.

Subani, W dan H. R. Barus. 1989 . Alat Penangkapan Ikan dan Udang Laut di Indonesia. Jurnal Penelitian Perikanan Laut. Jakarta. Departemen Pertanian. Balai Penelitian Perikanan Laut. 248 hal

Sudrajat, Siti Meilanisa N I., Rosyid, Abdul., Bambang, Azis Nur. 2014. Analisis Teknis dan Finansial Usaha Penangkapan Ikan Layur (Trichiurus sp) dengan Alat Tangkap Pancing Ulur (Handline) di Pelabuhan Perikanan Nusantara Palabuhanratu Sukabumi. Journal of Fisheries Resources Utilization Management and Technology. Vol 3, No 3, Tahun 2014, HIm 141-149

Supriadi., Yayu A. La Nafie dan A. I. Burhanuddin. 2004 . Inventarisasi Jenis, Kelimpahan dan Biomas Ikan di Padang Lamun Pulau Barranglompo Makassar. Jurnal Torani. Vol. 14(5) Edisi Khusus SP4, Desember 2004: $288-295$

Syahputra, R D., Aziz N B dan Dian A NND. 2016 . Analisis Teknis dan Finansial Perbandingan Alat Tangkap Bagan Tancap Dengan Bagan Apung di PPP Muncar Banyuwangi Jawa Timur. Journal of Fisheries Resources Utilization Management and Technology. Vol 5 (4), Tahun 2016, HIm 206-215

Utami, Eva. 2009. Analisis Respons Tingkah Laku Ikan Pepetek (Secutor Insidiator) terhadap Intensitas Cahaya Berwarna. Jurnal Sumberdaya Perairan. Vol 3 No. 2 Tahun 2009 ISSN 1978 -1652

Walpole. 1995. Pengantar Statistik. Jakarta (ID) : Gramedia Pustaka Utama

Zulkarnain. 2011. Efektivitas Bubu Lipat Modifikasi dan Penggunaan Cacing Tanah (Lumbricus rubellus) Sebagai Umpan Alternatif Untuk Penangkapan Spiny Lobster (Panulirus sp) di Perairan Pesisir Timur Teluk Palabuhanratu Jawa Barat. Buletin PSP. 19 (03). 1-84 